\title{
Die belang van gesinsbeplanning vir Suid-Afrika
}

\section{DIE BEVOLKINGSPROBLEEM IN DIE WERELD ${ }^{1.2}$}

Die wêreldbevolking neem tans teen 'n ongeèwenaarde tempo toe (figuur 1). Oor baie eeue heen het die bevolking konstant gebly, maar sedert die begin van die negentiende eeu skerp begin toeneem as gevolg van die impak van geneeskunde en tegnologiese vooruitgang. Die bedreiging wat hierdie bevolkingsontploffing vir die wêreld inhou, word die duidelikste gesien in ontwikkelende lande met toenemende hongersnood, behuisingstekorte, siekte-epidemies, ens. Aan die ander kant word ontwikkelde lande ook nie gespaar van die effek van oorbevolking nie, ten spyte van 'n laer groeikoers. Hier is toenemende besoedeling en uitputting van grondstowwe die hoofprobleme.

Tans is daar bykans 6000 miljoen mense op aarde. Vroeg in die 22ste eeu sal hierdie getal 100000 miljoen oorskrei. Aan die ander kant het die geboortesyfer per 1000 van die bevolking weliswaar die afgelope aantal jaar afgeneem:

\begin{tabular}{|l|c|c|c|}
\hline & $1950-55$ & $1990-95$ & $\begin{array}{c}2020-25 \\
\text { (geskat) }\end{array}$ \\
\hline Wêreldtotaal & 37,5 & 26,0 & 17,9 \\
\hline $\begin{array}{l}\text { Meer ontwikkelde } \\
\text { gebiede }\end{array}$ & 22,6 & 14,2 & 11,9 \\
\hline $\begin{array}{l}\text { Minder ontwikkelde } \\
\text { gebiede }\end{array}$ & 44,7 & 29,4 & 19,1 \\
\hline
\end{tabular}

Alhoewel hierdie geboortesyfer afgeneem het, sal die totale getal jaarlikse geboortes steeds bly styg, veral as gevolg van 'n vermeerdering in die getal vrouens in hul reproduktiewe jare. Die rede hiervoor is die jong gemiddelde ouderdom van die wêreldbevolking. Volgens die Wêreldgesondheidsorganisasie (WGO) se langtermynprojeksies sal die wêreldbevolking bly styg en uiteindelik stabiliseer by \pm 11600 miljoen kort na die jaar 2200. Dit is dus duidelik dat selfs 'n streng beleid van twee kinders per gesin baie lank sal neem om die verlangde effek op die totale bevolking te hê.

\section{DIE SITUASIE IN SUID-AFRIKA ${ }^{3,4,5}$}

Suid-Afrika is in dié opsig glad nie gespaar nie, veral omdat 'n groot deel van die bevolking in ' $n$ sogenaamde derdewêreldsituasie verkeer. Enkele van die Suid-Afrikaanse syfers sien soos volg daar uit:

\begin{tabular}{|l|c|c|c|c|}
\hline & Okt. 1994 & 1995 & 2010 & 2025 \\
\hline $\begin{array}{l}\text { Bevolkingsgrootte } \\
\text { (miljoene) }\end{array}$ & 40,7 & 43,5 & & \\
\hline $\begin{array}{l}\text { Geprojekteerde } \\
\text { bevolkingsgrootte }\end{array}$ & & & 57,5 & 70 \\
\hline
\end{tabular}

\begin{tabular}{|l|c|}
\hline & Oktober 1994 \\
\hline Natuurlike aanwaskoers & $2,3 \%$ \\
\hline Totale fertiliteitskoers & 4,1 \\
\hline Geboortesyfer & 23,4 per 1000 \\
\hline Sterftesyfer & 9,4 per 1000 \\
\hline Natuurlike aanwas & 14 per 1000 \\
\hline Persentasie van bevolking jonger as 15 & $37,1 \%$ \\
\hline $\begin{array}{l}\text { Kindersterftesyfer per duisend lewende } \\
\text { geboortes }\end{array}$ & 46 \\
\hline
\end{tabular}

Dit is bereken dat Suid-Afrika, veral wat die beskikbare waterbronne betref, nie meer as 80 miljoen mense kan akkommodeer nie.

Suid-Afrika het in 1974 begin met 'n Nasionale Gesinsbeplanningsprogram wat veral ingestel was op die beperking van geboortes. Hierdie program is dikwels deur sekere dele van die bevolking as ' $n$ bedreiging ervaar en meer kinders per vrou is dikwels in reaksie voorgestel.

Die klem is internasionaal besig om te verskuif van ' $n$ fokus op geboortebeperking na breë reproduktiewe gesondheidsorg waarvan gesinsbeplanning ' $n$ baie belangrike onderdeel is. Gesondheid word volgens die WGO gedefinieer as 'n staat van volledige fisiese, sielkundige en sosiale welsyn en nie slegs die afwesigheid van siekte of ongesteldheid nie. Reproduktiewe gesondheid behels alle aspekte van die reproduktiewe stelsel.

Die gevolge van die hoë groeikoers behels onder meer dat:

1. Suid-Afrika teen die jaar 2000 waarskynlik 1,6 miljoen meer kinders op skool sal hê as enige ontwikkelde land van dieselfde grootte. Die gemiddelde ouderdom van 
Suid-Afrika se bevolking is slegs 15 jaar, teenoor ongeveer 24 jaar in die res van die wêreld;

2. daar 210000 nuwe huise per jaar gebou moet word om die vraag na behuising te bevredig teen 'n koste van $\mathrm{R} 10,5$ biljoen per jaar;

3. meer as 1000 werksoekers, wat nie werk kan vind nie, daagliks die arbeidsmag betree. Daar word beraam dat 8 miljoen mense teen die jaar 2000 werkloos sal wees. Hongersnood, siektes en misdaad is faktore wat hieruit voortvloei.

\section{FAKTORE WAT DIE GEBOORTEKOERS KAN VERANDER ${ }^{\circ}$}

1. Beter gesondheid vir almal en minder kindersterftes Daar is bereken dat in die landelike gebiede van Indië 'n egpaar 5 kinders moet hê om 'n 95\%-kans te hê dat een seun volwassenheid sal bereik. Dit is duidelik dat 'n ouerpaar in 'n groot mate seker moet wees dat die paar kinders wat hulle wel het waarskynlik groot sal word. 'n Belangrike faktor wat kinderoorlewing negatief mag beïnvloed, is die afname in borsvoeding. Afgesien van die voordele vir die baba, het borsvoeding ook die bykomende voordeel dat dit ovulasie onderdruk en heel dikwels deur laer sosio-ekonomiese vroue gebruik word om geboortes te spasieer. Daar word bereken dat verlengde borsvoeding waarskynlik deur die jare meer geboortes voorkom het as al die moderne gesinsbeplanningsmetodes tesame.

2. Beter status in die samelewing vir vroue, veral deur hulle meer inspraak te gee in die getal kinders wat hulle wil hê.

3. Beskikbaarheid van gesinsbeplanningsdienste en gemaklike toegang tot hierdie dienste.

4. Opvoeding en geletterdheid, veral van vroue.

5. Meer werksgeleenthede. Sosio-ekonomiese ontwikkeling op sy eie lei tot 'n afname in die geboortekoers.

6. Later huwelike.

7. Migrasie na stedelike gebiede. Stedelike bevolkings is makliker bereikbaar met inligting en dienste.

Alhoewel verskillende kontrasepsiemetodes beskikbaar is, is die gebruiksyfer daarvan nie na wense nie. Die ideaal sou wees dat $80 \%$ van ' $n$ bevolking se vroue van reproduktiewe ouderdom, een of ander metode van kontrasepsie sal gebruik. Die situasie in die wêreld is soos volg:

Kontrasepsiegebruik in 1990 (vrouens, $15-49$ jaar)

\begin{tabular}{|l|c|c|}
\hline & $\begin{array}{c}\text { Egpare } \\
\text { (milj.) }\end{array}$ & $\begin{array}{c}\text { Gebruik } \\
\%\end{array}$ \\
\hline Wêreld & 899 & 57 \\
\hline Minder ontwikkelde lande & 710 & 53 \\
\hline Afrika & 97 & 18 \\
\hline Asië, Oseanië & 545 & 58 \\
\hline Oos-Asië & 236 & 79 \\
\hline Ander & 309 & 42 \\
\hline Latyns-Amerika en Karibies & 67 & 58 \\
\hline Meer ontwikkelde lande & 189 & 72 \\
\hline
\end{tabular}

Suid-Afrika (1990)

\begin{tabular}{|lc|}
\hline Gemiddeld & $53 \%$ \\
\hline Asiërs & $63 \%$ \\
\hline Swart & $45 \%$ \\
\hline Kleurlinge & $60 \%$ \\
\hline Wit & $66 \%$ \\
\hline
\end{tabular}

\section{WANPERSEPSIES}

Daar is baie wanopvattings in omloop in verband met die komplikasies van kontraseptiewe preparate. Een daarvan is dat kontrasepsie tot infertiliteit mag lei. Die ware toedrag van sake is dat alle hormonale metodes, asook spermdodende preparate en skansmetodes soos kondome, in der waarheid voorkom dat sperms, waaraan kieme kan kleef wat buisontsteking veroorsaak, deur die genitale traktus tot in die buise kan deurdring. Op hierdie manier word die fertiliteit dan eintlik beskerm. Ander belangrike gesondheidsvoordele van hormonale kontrasepsie sluit in: meer gereelde siklusse met minder voorkoms van bloedarmoede, minder pynlike menstruasie, minder kanker van die eierstokke en endometrium (baarmoeder) en minder siste van die eierstokke.

\section{TIENERSWANGERSKAPPE}

Daar word bereken dat 25-33\% van alle kraamgevalle in SuidAfrika onder tieners voorkom. Tienerswangerskap en -geboorte ontwrig die fisiologiese en intellektuele ontwikkeling van jong meisies, ontneem hulle van die moontlikhede van selfverwesenliking en daar is ook dikwels belemmering van die gesonde ontwikkeling van hulle babas. Behoorlike geslagsopvoeding en beskikbaarstelling van kontrasepsie is dus van die uiterste belang.

\section{ONGEWENSTE SWANGERSKAPPE'}

Daar word bereken dat die helfte van die wêreld se swangerskappe onbeplan is en 'n kwart daarvan ongewens. Ongeveer 500000 vroue sterf jaarliks as gevolg van die komplikasies van swangerskap en kindergeboorte, terwyl baie meer permanente skade opdoen, dikwels as gevolg van onveilige aborsies. Indien die swangerskap behou word, lei dit dikwels tot kinderverwaarlosing en gesinsgeweld. Die swangerskap is dikwels 'n hoërisikoswangerskap aangesien voorgeboortesorg glad nie of laat ontvang word. Indien die ongehude kind ' $n$ dogtertjie is, is haar kanse ook groot om in dieselfde situasie as haar tienerma te beland. Behoorlike gesinsbeplanning moet dus toegepas word sodat elke kind ' $n$ beplande en welkome kind is - dit sal moontlik ' $n$ invloed hê op die 4,3 miljoen pasgeborenes wat jaarliks sterf.

\section{TERMINASIE VAN SWANGERSKAP`}

Ongeveer $63 \%$ van die wêreldbevolking het tans toegang tot aborsie op versoek, terwyl die res onderworpe is aan wisselende vorms van wetgewing waar aborsie onder sekere voorwaardes toegestaan word. Jaarliks word ongeveer 3653 miljoen ongewenste swangerskappe getermineer, hetsy wettig of onwettig. Daar word bereken dat $30-50 \%$ van alle vroue in die wêreld minstens een terminasie in haar lewe 
ondergaan.

Dit is onwaarskynlik dat aborsie op aanvraag 'n betekenisvolle invloed op die geboortesyfer sal hê. Aan die ander kant sal wettige aborsies, wanneer meer vrylik beskikbaar, wel moederlike sterftes en ander komplikasies as gevolg van onveilige (onwettige) aborsies verminder. Behoorlike kontrasepsie sal natuurlik dieselfde doel bereik met minder konflik. Hier is veral noodkontrasepsie (die sogenaamde oggend-daarna-metodes) ook ter sprake.

\section{SLOTOPMERKINGS}

Gesinsbeplanning is by uitstek 'n voorkomende gesondheidsmaatreël. Die belangrike voordele van behoorlik beplande swangerskappe moet beklemtoon word en die doelstellings van gesinsbeplanningsprogramme behoort nie beperk te word tot slegs die vermeerdering van kontrasepsiegebruikers nie. Myns insiens het die mediese wetenskap die mensdom op hierdie gebied in die steek gelaat deurdat so lank geneem is voordat veilige, betroubare kontrasepsiemetodes ontwikkel is. Afgesien van enkele uitsonderings was die grootste ontwikkeling op die gebied van kontrasepsie in die sestigerjare en hoewel verfyning van metodes sedertdien plaasgevind het, is min werklike vordering in die laaste 25 jaar gemaak. Verder is die huidige metodes steeds vir baie vroue nie beskikbaar nie.

'n Groot tragedie is die gebrekkige insig en selfdissipline by die wêreldbevolking, weer eens veral in die onderontwikkelde dele van die wêreld, betreffende hul insig in die bedreiging van oorbevolking en onderbenutting van kontrasepsie. 'n Grootse poging is nodig om die groeikoers in die getal mense op aarde drasties te laat afneem, anders staar groot rampe ons in die gesig - ook in Suid-Afrika.

\section{Departement Obstetrie en Ginekologie, Universiteit van die Oranje-Vrystaat, Bloemfontein}

\section{LITERATUURVERWYSINGS}

1. Fathalla, M.F. (1995). Population concerns for the next century. Uitnodigingslesing gelewer tydens die $15 \mathrm{e}$ Wêreldkongres oor fertiliteit en steriliteit, Mont Pellier, Frankryk, 17-22 September 1995.

2. Guillebaud, J. (1993). Contraception your questions answered. 2nd ed. (Churchill Livingstone, Singapoer).

3. Klugman, B. (1993). Balancing means and ends - population policy in South Africa, Reprod. Health Matters, 1, 44-57.

4. Ministerie van Welsyn en Bevolkingsontwikkeling. (1995). 'n Groenskrif vir openbare bespreking: Bevolkingsbeleid vir SuidAfrika (Promedia, Pretoria).

5. Rees, H. (1995). Sexual and reproductive health in South Africa: a new concept in changing health services, Sexual and Reprod. Health Bull. 1, 2-3.

6. Khanna, J. (1994). Reproductive health and reproductive choice: the WHO perspective. Progress in Human Reprod. Res., 30, 2-3.

7. Safe motherhood, reproductive health and population policies. (1994). Safe Motherhood Newsletter, 14, 4-6.

8. Van Look, P.F.A. \& Von Hertzen, H. (1993). Induced abortion. In Frontiers in Endocrinology: Reproductive Health 1989-92 (AresSerono Symposia Publications, Rome). 